International Journal of English Literature and Social Sciences
Vol-6, Issue-1; Jan-Feb, 2021
Journal Home Page Available: https://ijeab.com/
Journal DOI: $10.22161 /$ ijels

\title{
Cultural Negotiation of Immigrants in Jhumpa Lahiri's Narratives
}

\section{Nagendra Bahadur Bhandari}

Department of English, Prithvi Narayan Campus, Tribhuvan University, Nepal

Received: 11 Nov 2020; Received in revised form: 21 Jan 2021; Accepted: 01 Feb 2021; Available online: 10 Feb 2021

(C)2021 The Author(s). Published by Infogain Publication. This is an open access article under the CC BY license

(https://creativecommons.org/licenses/by/4.0/).

Abstract- This article analyzes the cultural negotiation and identity formation of immigrant characters in Jhumpa Lahiri's narratives. In the transcultural space of diaspora, the immigrant characters often vacillate between cultural practices of their home and host country problematizing their cultural identity. They can neither forsake their past: cultural origin nor fully emerge into the cultural practices of their host country. They tend to adopt the new cultural identity without leaving the old one. In a sense, they occupy a shared cultural space of their host and home country rendering cultural ambivalence. Such cultural negotiations lead them to the third space: hybrid cultural space which renders new form of fluid and dynamic cultural identity that transcends the binary of the past and present, and home country and host country. Formation of such unstable cultural identity of immigrants is examined in the critical frame of Stuart Hall's cultural identity and Homi K Bhabha's third space in this article.

Keywords-Being, Becoming, Diaspora, Identity, Third Space.

\section{INTRODUCTION}

Diasporic literature deals with the problematic cultural identity of immigrants resulting from shifting of cultural and geographical space. Such writings try to explore the problems of transformation of the native into something other than themselves or at least one who is in a crisis regarding his ther own cultural identity. The immigrant characters find themselves in a struggle to establish an identity: feeling conflicted between two cultures; one their own native culture and the other an alien culture. There is always a tension between desires to belong to the new society and an urge to retain the culture of the old one. The tension renders identity crisis.

The Indian American writer Jhumpa lahiri explores the problematic cultural identity of Indian immigrants living in the American diaspora in her narratives. She was a daughter of Bengali parents and was brought up in the west. She herself was influenced by both Indian and American culture and heritage. This multi cultural experience plays vital role in many of her stories and novels which depict the alienation and loneliness of immigrants caught up between two drastically different worlds.

In 1999, Lahiri published her first short story collection Interpreter of Maladies. The nine stories of this collection share common themes such as the sense of loss, marital problems, and the importance of communication in Indian immigrant families. The subtitle of the collection is "Stories of Bengal, Boston and Beyond", which points to the multicultural context of its characters, most of whom are from India (Bengal), immigrate to the United States and settle in the Boston area. However, the use of 'beyond' indicates that their diasporic journey beyond geographical space. Instead, it can be viewed as a rich, universal experience that connects people across globe. In 2003, she published her first novel, The Namesake, originally a novella in The New Yorker. It recounts the story of the Ganguli family, an Indian family with first-generation immigrant parents with their two children raised in the US. 
Her third book, Unaccustomed Earth (2008); a collection of short stories also explores the theme of the cultural dissonances experienced by immigrants caught between the culture of their Indian birthplace and the unfamiliar ways of their adopted home. The focus is on lives of second-generation immigrants who must navigate both the traditional values of their immigrant parents and the mainstream American values of their peers. Her second novel The Lowland (2013) explores the parents child relationship and the quest of self definition in the context of Bengali immigrants to America. She also enlarges her investigation, encompassing the effects of the Naxalite movement on a society and especially on a family. It is set in the background of the origin and development of Naxalite movement, and further explores the feminist perspective of a woman who undergoes from different phases. These narratives of Lahiri invite wide range of critical responses analyzing different aspects of immigrants' lives.

\section{REVIEW OF LITERATURE}

Critics vary in their analysis to Lahiri's writings. Critic Karunesh (2013) relates Lahiri's writings with her own experience of living in diaspora being the daughter of immigrant parents. He remarks that her writing has been shaped and influenced by her own experience of living in America and England as a second generation immigrant and occasional visits to India with her parents. Critics like Jagadish Barta (2010), Sugata Shamanta (2014) and Judith Caesar (2003) further extend their analysis relating to the experience of immigrants. Barta explores Lahiri's works relating with alienation, nostalgia and uprootedness of immigrant experience. However, Shamanta and Caesar think the diasporic condition as an opportunity to expand personal experience and knowledge. Such condition also demands openness, flexibility and adoptability to cope up with new situation. Dynamic characters enjoy such situation whereas others suffer.

Critics like Noelle Brada-Williams (2004), Michiko Kakutani (2008), Lavina Dhingra (2012) and Floyd Cheung (2012) do not only relate Lahiri's writing to the experience of immigrants. They think that her writing deal with universal human experiences and the problems inherent in human relation such as parents and children, husband and wife. Unlike other critics Anjali Tripathy (2014) explores the changing notion of Indian masculinity in diasporic context in Lahiri's writings. She remarks that Indian males have become less authoritative and more tolerant and flexible undergoing through the interaction with American culture.
Critic Bipasha Majumder (2016) anlysizes Lahiri's writing's relation with ecological concern and thinks that she highlights the need of ecocentric attitude. Thus, critics explore autobiographical elements, sense of uprootedness of immigrants, flexibility and openness in diaspora, human condition, flexible masculinity and ecological concerns in Lahiri's writings. In this sense, the cultural negation of immigrants and its repercussion on their cultural identity formation retain relevance for further inquiry.

\section{METHODOLOGY: CULTURAL IDENTITY}

Stuart Hall (1994) conceptualizes two types of cultural identity. The first is essentialist identity which defines cultural identity in term of one shared culture: a sort of collective one true self which people with shared history and ancestry hold in common. He explains:

The first position defines 'cultural identity' in term of one, shared culture, a sort of collective 'one true self', hiding inside the many other more 'selves', which people with a shared history and ancestry holds in common. Within the term of this definition, our cultural identities reflect the common historical experiences and shared cultural codes which provide us 'one people' with stable unchanging and continuous frame of reference and meaning. (p.223)

Such concept of identity claims that there is an authentic cultural identity, a true self, which people with shared history and ancestry hold in common. The "oneness" is understood as a stable, unchanging and continuous frame of reference and meaning that reflect the general shard cultural codes and common shared historical experience of people.

Along with the point of similarity, cultural identity also has the critical points of deep and significant difference, which constitute what we really are or rather what we have become. This is second dimension of cultural identity. Hall claims such identity as ongoing process of becoming and as well as being. It belongs to the future as well as past. He further explicates:

It is not something which already exists, transcending place, time, history and culture. Cultural identities come from somewhere, have histories. But, like everything which is historical, they undergo constant transformation. Far from being eternally fixed on some essentalized past, they subject to the continuous 'play' of history, culture and power. (p. 225) 
Identities are not externally fixed in some esssentalized past. They are subject to the continuous play of history, culture and power. The power relation between and among cultures affect the way in which these identities are subject and positioned in the dominant regimes of representation.

By analyzing the formation of human identity in postcolonial context, Homi k Bhabha (1994) argues that culture does not exist in isolation. It interacts and negotiates with other culture. Such process renders cultural transformation. His concept of identity is related to the cultural transformation. Cultural transformation is a process specifically that takes place among immigrants. The connections between immigrants and their home countries, as well as the political status of both home and host countries, affect the ways in which they adjust to a new location. The interaction and engagement in transcultural conversation between the host or dominant cultural groups and immigrant groups slowly opens up the new site for transformation. As such, cultural transformation characterizes the in-between as a third element, an amalgam of two cultural entities that create a third identity after the original two have been altered. In this context, cultural transformation becomes related to Bhabha's notion of third space.

To discuss the cultural identity of immigrant, Bhabha claims that third space "is characterized by discursive conditions of enunciation that ensure that the meaning and symbols of culture have no primordial unity or fixity; that even the same signs can be appropriated, translated, and rehistoricized a new" (p. 2). That is, "Third Space" is a place where we negotiate between different identities. Negotiation becomes a process where people of different cultures accept and blend their cultures in society without one culture dominating the other. This co-existence of different cultures ultimately produces a hybrid culture which Bhabha posits as "the inter-the cutting edge of translation and negotiation, the in-between space-that carries the burden of the meaning of culture" (p.2). For Bhabha "the importance of hybridity is not to be able to trace two original moments from which the third emerges, rather hybridity is the Third Space" (p.1), this enables other positions to emerge. Hybridity is a dual culture and also implies a syncretic view of the world in which the notion of fixity or essentiality of identity is continually contested. Hybridity is not just an amalgamation cultural materials or identities. It is the intercultural space of in-betweenness and liminality where identity is formed through the negotiation between different cultures.

\section{ANALYSISY: CULTURAL NEGOTIATION OF IMMIGRANTS}

Cultural identity of immigrants is a problematic issue since they are culturally, psychologically and emotionally living in two spaces: home land and host land. Lahiri often explores the problematic cultural identity: the bicultural affiliations of Indian immigrants living in the US in her novels and short stories. These immigrants simultaneously follow cultural practices of the both spaces: their origin India and host country the US. Although they are geographically far away from their cultural origin: being in Hall's (1994) term, they often show their attachment with it through various cultural semiotics like food, dress up, rituals. At the same time, they tend to adopt the cultural practices of their home land: becoming in Hall's (1994) term. Oscillating in these cultural spaces, they involve in the process of cultural negotiation which ultimately contribute in the formation of their cultural identity. However, the firstgeneration immigrants who have left their native country and settle down in the diaspora and the second-generation immigrants: the children of the first-generation immigrants who are brought up in the diaspora undergo in the process of cultural negotiation in diverse manner.

\subsection{Immigrants and Origin}

The first-generation immigrant characters in Lahiri's narratives try to follow and preserve the cultural practices of their native land: India although they are living in America, They are aware of their origin, They allow the host culture only partially to intrude at their home in the US. They maintain their ties with the Indian culture through the perpetuation of traditions and rituals alongside gatherings of fellow compatriots. They also manifest their attachment with their origin through preparing and consuming typical Indian food, wearing traditional Indian dress and occasional visits to India. Though they are geographically far away from India, India still remains a home for them.

The first-generation Indian immigrant characters consider Indian is their real home although they are far away living in the diaspora. In Interpreter of Maladies (1999), Eliot, for instance, in the story "Mrs. Sen's" understands Mrs. Sen's fondness for her home: '" When Mrs. Sen said home, she meant India, not the apartment where she sat chopping vegetables" ( Lahiri, 1999, p.116). Moreover, these immigrants perpetuate the customs and practices of their origin in their new home of diaspora. For instance, Mrs. Sen does not forget to mark her head with vermilion in spite of being in a foreign land. She sits on her floor everyday 
chopping vegetables in the same way she did in India, with the same knife she used there. She doesn't use a conventional western knife. Neither Mr. nor Mrs. Sen wear shoes inside (Indian habit), but they keep their sleepers and shoes in a by the front door. Being homesick, Mrs. Sen longs for the lively Indian community. The immigrants like Mrs. Sen searches the company of Indian immigrants for her emotional and psychological relief. In "When Mr. Pirzada Came To Dine" the second generation Indian immigrant Lilia observes her parents closely: "who used to trail their fingers at the start of each new semester, through the columns of the university directory, circling surnames familiar to their part of the world" (Lahiri, 1999, p 24). These immigrants experience a dire need to meet and talk with fellow immigrants from their homeland. They tend to show their attachment with their origin in the company with compatriots and other cultural semiotics.

Lahiri uses food items as manifestation of cultural bounding and disintegration. In "When Mr. Pirzada Came to Dine" food enacts as a means of attachment with motherland. Food is the factor that binds Mr. Pirzada with Lilia's family. Mr. Pirzada comes from Bangladesh whereas Lilia's parents are from India. These first-generation immigrants from the Indian subcontinent relish the same food and this establishes affinity between them. They eat pickled mangoes with their meals and eat rice every night for supper with their hands. Lilia observes that "like my parents, Mr. Pirzada took off his shoes before entering a room, chewed fennel seeds after meals as a digestive, drank no alcohol, for dessert dipped austere biscuits into successive cups of tea" (Lahiri, 1999, p 25). In the same way, Lahiri's another story, "The Third and Final Continent" revolves around the life of a Bengali gentleman who pursues his studies in Britain and his job in the US. They prefer to eat typical Indian food: steamed rice and a dish of chicken made with fresh garlic and ginger. In spite of their contact with three continents, they still maintain their Indian cultural identity and food is one of the most important factors that help them in retaining their Indianness.

These immigrants also nostalgically recall the moments they have experienced in their homeland while leading lives in the diaspora. In "The Temporary Matters" the Indian immigrant Shoba remembers that whenever there was a power-cut in India, they would say something, invariable; it would be a story, a poem, a joke or anything (Lahiri, 1999, p 13). This memory of her homeland helps her cope up with the loneliness living in the diaspora. She suggests her husband Shukumar, "How about telling each other something we've never told before" (Lahiri, 1999, p 13) during the consecutive five days power cut off from $8: 00$ to 9:00 $\mathrm{pm}$ for the repair of the electric line damaged by the storm. By reenacting the Indian tradition of telling each other stories and secrets, the couple mends their strain relationship which has been jeopardized after the stillbirth of their child. The power cut off and repairing process also connote the harmonizing process of their troubled relationship of the couple by following the Indian tradition of telling each other stories among family members in the evening. Apparently, the immigrants get back to their origin in order to overcome the adversities and difficulties in the diaspora.

In the same way, Ashima practices Indian cultural values at her new home in Boston in an attempt to get rid of the loneliness in The Namesake (2006). She preserves the Indian food recipes, the Indian dress, such as sari; a typical dress of Indian married women. Moreover, she never forgets to wear bindi that usually adorns the forehead of an Indian married woman. She cooks Indian foods: "combining Rice Crispies and Planters peanuts and chopped red onion in a bowl; she adds salt, lemon juice, thin slices of greenchili pepper, wishing there were mustard oil to pour into the mix" (Lahiri, 2006, p.6). She prefers to read "a tattered copy of Desh magazine" printed in her mother tongue. She does not call her husband with his first name; a typical practice of India and Nepal. In this part of the world, wife calls their husband with the name of the first child plus "father"-for example, Gogol's father. She perpetuates the Indian cultural practices deeply rooted in her subconscious even though she is living in the US.

Like Ashima, Moushumi's mother is also a typical example of an Indian wife. Like a traditional woman in India, she does not hold a job, but remains a homemaker. She does not know much about outer world. She has lived abroad for thirty-two years, in England and now in the United States but she:

does not know how to drive a car, does not have a job, and does not know the difference between a checking account and a savings account. And yet she is a perfectly intelligent woman, was an honors student in philology at Presidency College before she was married off at twenty-two. (Lahiri, 2006, p. 6)

She follows the life of a typical Indian woman despite living in the West for long period of time. She seems preoccupied with her cultural origin resisting the intrusion of the Western cultural practices of the diaspora. 
Similarly, in Lahiri's another novel lowland Indian immigrant Subash tries to search India at Rhode Island in the US. He searches commonalities between the two places. Both Rhode Island and Calcutta have "mountains to the north, an ocean to the east, the majority of land to the south and west" (Lahiri, 2013, p. 34). Being close to sea level, these two places have estuaries where fresh and salt water combine. Subhash, in an imaginary geographical juxtaposition between homeland and adoptive land, searches his origin in the diaspora. Besides the location, the date in calendar transports him to his native land. One evening, at his American girlfriend Holly's place, he glances at the calendar and notices that the following day is August 15, Indian Independence Day, a holiday in his home country, an ordinary day in the United States. He remembers that in August 1947, while India was celebrating, both Subhash (close to four year) and Udayan (just two year) had a fever and were taken to the doctor. This represents the earliest memory of his childhood, one that comes back to him. Thus, he constantly manifests his preoccupation with his homeland while living in the diaspora.

In the same way in the title story" Unaccustomed Earth" of the collection entitled Unaccustomed Earth (2008) Ruma's father has his native culture engrained within the soul. He endeavors to teach his grandson Bengali words. In Bengali culture, parents expect the support of their children, physically or at least mentally in their old age. Another character in the story, Ruma's mother is presented off screen as she is already dead when the narration begins. Yet she remains quite influential in Ruma's life. She even criticizes Ruma for marrying a white American boy: "You are ashamed of yourself, of being Indian that is the bottom line" (Lahiri,2008, p. 26). To her, marrying a white boy originates from a sense of disrespect for her own culture. She has deep respect for the culture of her origin. Her death signifies the loss of the bridge between two cultures to her daughter.

Briefly, the first-generation Indian immigrants manifest their attachment with their cultural origin in various ways although they are living in the diaspora. They often show their preoccupation with their cultural root through cultural semiotics like food and dress up. Moreover, they harmonize their troubled relationship and overcome the adversities of immigrant lives getting back to their origin. Moreover, they get easily transported to their homeland on the perceived resemblances in geographical location and in the important date of their national history. Furthermore, some of them are content leading typical Indian style lives even in the US. Likewise, some of them tend to enact as a cultural transmitter of their culture to their children and grandchildren. Despite their preoccupation with their cultural origin, they also gradually adopt the cultural process of their host land in their becoming process.

\subsection{Immigrants and Acculturation}

The first-generation Indian immigrant characters negotiate and transform in varying degree in their new cultural milieu of host country although they often show their attachment with their cultural origin. Their 'being', in Hall's (1994) terms, undergoes in the process of constant negotiation and transformation. Consequently, they seem to adopt the Western values and customs of their hostland. In "When Mr. Pirzada Came to Dine" the Indian mother learns to celebrate American festival Halloween with her daughter and then introduces it to Mr. Pirzada. Moreover, she assures Mr. Pirzada that there is no danger in letting Lilia goes outside at night and that "all the children will be out" (Lahiri, 1999, p. 38). In addition, the mother helps Lilia to prepare her witch costume for Halloween. Unlike Indian mother, Mrs. Sen starts doing part time job of babysitting. She takes adventurous decision of driving her husband's car to buy fish though it ends with a minor accident. These Indian women immigrants involve in the process of cultural negotiation and partially adopt the cultural practices of their host land.

Similarly in "Interpreter of Maladies", The Das family looks like Indian but dresses and behave as Americans do. Lahiri presents Mr. Das as a representative of the American life. A clean-shaved man, he looks exactly a typical American. He has a sapphire blue visor, and was dressed in shorts, sneakers, and a T-shirt. The camera slung around his neck, with an impressive telephoto lens and numerous buttons and markings. His wife, Mina Das represents the American woman who "wore a red-and-whitecheckered skirt that stopped above her knees, slip-on shoes with a square wooden heel, and a close-fitting blouse styled like a man's undershirt. The blouse was decorated at chestlevel with a calico applique in the shape of a strawberry" (Lahiri, 1999, p. 46). Like the Americans, Mr. Das addresses to his wife by her first name. This Indian couple seems to be fully immersed into American way of life.

In the same way in Namesake, Ashima gradually adopts American values and system despite her initial resistance. She enters the U.S. culture of individualism by going out and buying her groceries and pushing a stroller like all American mothers. She begins to trust the American system and to feel "connected to Cambridge in a way she has not previously thought possible" (Lahiri, 2006, p.6). She 
learns practices of American people. She starts inviting American women: her shopping companions to her home. She also knows about other American women living alone because they are divorcees and about dating in middle age. She becomes more tolerant of her children's Americanization. She also starts celebrating Christmas and Thanksgiving. She even makes her own Christmas cards, decorating them with elephants and other typical Indian drawings. Gradually, the Indian immigrants adopt the Western cultural practices of their host land.

Unlike other first-generation immigrants, Gauri adopts American culture in drastic manner in Lowland. She changes her appearance in order to deny her Indian ancestry. She destroys her Indian saris and trims her hair very short. One day, arriving home from work, Subhash, her husband, finds that "all of her saris, and her petticoats and blouses, were lying in ribbons and scraps of various shapes and sizes, as if an animal had shredded the fabric with its teeth and claws" (Lahiri,2013, p.141). Subhash demands from Gauri a reason why she has done so and she just explains she was tired of the Indian clothes and her long hair. Gauri decides to blend in the American society, wearing jeans and western clothes. When Bela, Gauri's daughter is born, Gauri does not teach her the Indian traditions of dress up and hairstyles. Unlike Indian mother, she devotes more time for her study instead of caring her baby daughter. Moreover, she forsakes her daughter and husband for the sake of her career and individualism. In this way, the cultural negotiation of the first generation immigrants involve in constant oscillation between their Indian cultural origin and Western cultural practices of their host country. Unlike their parents, the hybrid cultural upbringing remains detrimental in the cultural negotiation of the second-generation immigrants.

\subsection{Immigrants and Cultural Hybridity}

While negotiating between two cultural spaces: home and host country, the immigrants hybridize the cultural practices of the both spaces. The cultural hybridity is apparent in hybrid cultural practices in the first-generation immigrants. Unlike their parents, the second-generation immigrants experience the cultural hybridity in their childhood. They are brought up between two diametrically different cultures, similar to Bhabha's in-between space. They are both Indian and American. They belong to Indian parents on a different geographical space than India and are acculturated as an Indian at home. But outside the home, they are American. They think of India as a foreign country far away from home. They struggle to reconcile their dual cultures.
In "When Mr. Pirzada Came to Dine" Lilia; the second-generation immigrant has exposure with Indian way of life at her home. Her mother cooks Indian food, her parents speak Bengali; and they are forever concerned about India and what is happening there. Lilia's innocent mind cannot understand the issues like Partition, the Civil War in East Pakistan, the fleeing refugees and the frequent communal clashes. Rather she waits for the candy Mr. Pirzada brings everyday for her. She could not understand how Mr. Pirzada could be different from her parents. But she is exposed with the Western way of life outside her home. In fact, she grows up negotiation between two worlds, two cultures and two world views.

Growing up negotiating between two cultures, some of the second-generation immigrants tend to be flexible and open. In "Blessed House" the newly married girl Twinkle seems to be open and experimental when she finds treasures of Christianity in her new house. Unlike her husband, she flexibly prefers in keeping those things in her house. In fact, she has attitude like that of cosmopolitan character. For instance, she likes more her American nickname than her Indian name; she has had several lovers, her research includes an Irish poet, she enjoys listening to jazz, and she does not like to cook Indian dishes. Although her connections with her Indian heritage seem frail, she agrees to marry a fellow Indian-American whom she hardly knows in a traditional ceremony. She is not a compliant wife but in the end she seems to compromise to make her conjugal life successful. Moreover, she manages the Christian objects in their home being open-minded and flexible for cultural and religious diversity. The cultural in-betweenness affects the lives of both generation immigrants and their perceived gender roles also.

The cultural negotiation in the diaspora also contributes in the negotioation of the gender roles in both generation immigrants' lives. Lahiri also exposes the positive outcomes of the in-betweenness in redefining traditional gender roles of Indian immigrants in "A Temporary Matter". The traditional gender role of husband and wife is reversed in the life of the couple portrayed in the story. Shoba and her husband Shukumar reverse the traditional husband and wife role: "The more Shoba stayed out, the more she began putting in extra hours at work and taking on additional projects, the more he wanted to stay in, not even leaving to get the mail, or to buy fruit or wine" (Lahiri, 1999, p. 2). Shukumar has accepted cooking as his responsibility. He also involves in other household works: "gathered onion skins in his hand and drop them in the 
garbage pail," and "ran the water in the sink, soaking the knife" (p. 5), while Shoba is indifferent toward the house and "treats [it] as if it is a hotel" (p. 6). Besides redefining the gender role, the cultural negotiation in the diaspora renders a question of belonging in the second-generation immigrants.

In Namesake, Gogol, the second-generation immigrant faces a question of his belonging. He is an exemplary of ABCD (American Born Confused Deshi) who cannot answer the question, "Where are you from?"(Lahiri, 2006, p. 6). For him the notion of home is very complicated. $\mathrm{He}$ is baffled to answer whether he is from India or the United States. However, Gogol does not think of India as his country or "desh;" he sees himself as purely Americanunhyphenated Indian American. He struggles to reconcile his dual cultures. On the one hand, he is fascinated with the free and happy lifestyles of his American girlfriend, Maxine. On the other, he feels a sense of obligation towards his parents. As a second-generation immigrant, Gogol negotiates his identity in the midst of differences. Moreover, the treatment of the dominant group remains crucial in their sense of belonging. In his twenty seventh birthday, Pamela, a middle aged white woman insists him to be Indian, though he declares that he is from Boston. She states that he won't get sick when he travels to India but Gogol denies it. He tries to identify himself with America. Despite affiliation with the host country, Gogol's identity formation, then, demands awareness and recognition of his Indian origin: being.

Negotiating in the diaspora, Ruma's personality has a double perspective in "Unaccustomed Earth". On the one hand, she has married an American boy despite opposition of her mother who "had done everything in her power to take Ruma out of marrying Adam, saying that he would divorce her, that in the end he would want an American girl" (Lahiri, 2008, p.26). On the other, she does not like the American way of parenting: "In spite of her efforts he [ her son Akash] was turning into the sort of American child she was always careful not to be, the sort that horrified and intimidated her mother" (p.23). Her embarrassment is apparent to the sight of her father who appears to her resembling "an American in his old age. With his gray hair and fair skin he could have been practically from anywhere"(p.11). Ruma opines that "it was her mother who would have stuck out in this wet Northern landscape, in her brightly colored saris, her dimesized maroon bindi, her jewels"(p. 11) is deeply rooted in her nostalgia for her ancestral culture.

In "Only Goodness" Rahul leads a distressing life to live in-between two cultures. He is the product of hybrid culture having respect to none of the cultures. He has been constantly compared to other Indian children for years. Indian life holds no charm to him and, unlike his sister, he has no romantic viewpoint towards immigration:

While Sudha regarded her parents' separation from India as an ailment that ebbed and flowed like a cancer, Rahul was impermeable to that aspect of their life as well. 'No one dragged them here,' he would say. 'Baba left India to get rich, and Ma married him because she had nothing else to do'. (Lahiri, 2008, p.138)

Rahul negotiates between his own wish to live an American way of life and his parents' expectation of maintaining his Indian cultural origin. $\mathrm{He}$ is unable to counterbalance the pressure and takes recourse on alcohol.

Like Rahul, in part two of the collection, "Hema and Kaushik"(which is a collection of three interlinked stories), the leading characters Hema and Kaushik suffer from the trauma of being dislocated. Though Hema can have a negotiation with her past, Kaushik who is of melancholic nature cannot escape from it. Hema suffers from her inbetween stage, the aspiration to marry a white man and the final retreat to her Indian culture. Kaushik's sense of rootlessness comes from his father's remarriage and ultimately he fails to keep the balance and dies in a tsunami in Indonesia. The sense of alienation and displacement works within both of them in different degrees and in different ways. Thus, negotiating in the cultural inbetweenness of the diaspora, the both generation immigrants undergo in the process of cultural negotiation in heterogeneous manner. Broadly, they simultaneously follow the cultural practices of their origin: being and adopt the cultural practices of the host land: becoming, and manifest an ambivalent attitude to the both.

\section{CONCLUSION}

In Lahiri novels and short stories, the first and second-generation immigrant characters negotiate their cultural identity in the diaspora. The first-generation immigrants are mainly from Bengal of Indian and pursuing their career and higher education in the US. Their native culture is deeply rooted in them and they try to preserve it in the foreign land in varying degree. They also try their children to follow the same to some extent. However they show different degree of flexibility and adoptability to the Western culture of their host land. In the same way, the second- generation immigrant characters, the children of first-generation immigrants, are also living in cultural hybrid 
space. In home, they are exposed with Indian culture. But they learn and live in America culture outside of their home. Their aspiration of assimilating in main stream American culture is questioned due to their biological heritages. Thus, characters of both generations oscillate between the Indian and American culture. They cannot totally forsake one culture and follow the other. They follow both the cultures at the same time.

The characters oscillate between two cultures because they are not totally free from their shared and common ancestry and history; which Hall calls 'being'. At the same time they are negotiating with their present and reforming themselves; which Hall calls 'becoming'. In fact the ' being' and 'becoming' both are part of cultural identity. Moreover, their cultural interaction result ambivalence in them. They get simultaneously attracted and distracted to both their present and past. Such interaction leads these characters in the cultural hybrid space which Bhabha terms as 'third space'. It is doubling and assembling space of being in at least two places at once. These immigrants' cultural identities constantly negotiate and transform in the third space. So their identities are not fixed and stable rather fluid and ever changing.

\section{REFERENCES}

[1] Ashcroft, B., Gareth G.\& Helen T. (1989). Key concepts in postcolonial studies. Routledge.

[2] Batra, J. (2010). Jhumpa Lahiri's Namesake : A critical study. Prestige Books.

[3] Bhabha, H. .K. (1994). The location of culture. Routledge.

[4] Brada- W. N. (2004). Reading Jhumpa Lahiri's Interpreter of Maladies as a short cycle. MELUS, 29 (3-4), 451-464.

[5] Caesar, J. (2003). Beyond cultural identity in Jhumpa Lhiri's when Mr. Pirzada came to dine. North Dakota Quarterly, 70 (1), 82-92.

[6] Cordelia, D. E. (2011). The treatment of immigrant experience in Jhumpa Lahiri's The Namesake. The Criterion: An International Journal In English, II (IV), 2011,1-9.

[7] Dhingra, L. \& Floyd C.(Eds) . (2012). Introduction. Naming Jhumpa Lahiri: canons and controversies . Lexington Books.

[8] Hall, S. (1994). Cultural Identity and Diaspora. In P. Williams \& L. Chrisman (Eds), Colonial discourse and post colonial theory: A reader (pp. 222-237). Columbia UP.

[9] Kakutani, M. (2008). The Sense of exile, alienation and assimilation in Jhumpa Lahiri's fiction. In S. Singha (Ed), Post colonial Writers New Perspectives (pp. 77-86). Atlantic.

[10] Karunesh (2013). Diasporic crisis of dual identity in Jhumpa Lahiri's The Namesake. International Journal of Multidisciplinary Academic Research, 1 (1), 25-30.
[11] Lahiri, J. (1999). Interpreter of Maladies. Houghton Mifflin Harcourt.

[12] Lahiri, J. (2006). The Namesake. Harper Collins.

[13] Lahiri, J. (2008). Unaccustomed Earth. Random House.

[14] Lahiri, J. (2013). The Lowland. Random House.

[15] Majumder, B. (2016). Practical ecocriticism and Jhumpa Lahiri's The Lowland: An Analysis. International Journal of English Language, Literature and Humanities, IV-V, 383390.

[16] Shamanta, S. (2014). Transplanted individual: Anxiety of dislocation and cultural alienation in Jhumpa Lahiri's Unaccustomed Earth. The Criterion: An International Journal in English, 5(6), 307-317.

[17] Tripathy, A. (2014). Marginalized musculinity: A Study of Jhumpa Lahiri's Namesake. International Journal of English Language and Translation Studies, 1 (4), 74-79. 